\title{
The Study on University "Highly Educated High Professional Titles” Teacher Joining Party Way in New Period
}

\author{
Guohua Ge \\ Jiangxi Science \& Technology Normal Univerity, Jiangxi China 330013
}

\begin{abstract}
Pay attention to the development of high education, high titles of intellectuals into the party is the Party Construction in the new century and the new task, it is to carry out the spirit of the 17th Party Congress, implement the scientific outlook on development needs. Play double personnel advantages, innovative work of Party member development, explore the effective way and method, active well high work of Party member development, promoting the new great project of Party building, to achieve the goal of building a well-off society has important sense.
\end{abstract}

Keywords- Highly Educated High Professional Titles; Joining Party Way; New Period

\section{INTRODUCTION}

Pay attention to the development of high education, high titles of intellectuals into the party is the Party Construction in the new century and the new task, it is to carry out the spirit of the 17th Party Congress, and implement three represents important thought and the scientific outlook on development needs. High education, high titles of pair of personnel, they are the major forces to build and develop, development high staff to join the party is not only the university party building work is one of the important content, is the oneself construction that strengthens a party, improve the combat effectiveness of the party needs, is to promote college development initiatives. Promoting the new great project of Party building, to achieve the goal of building a well-off society has important sense. Guangxi University party actively explore new situation in high staff work of Party member of the development method.

Size, pay attention to grasp the high staff characteristics, in-depth survey, in the light of its general trend, positive guidance, make it into development high staff join advantage, the correct analysis of treating high officers in the party's attitude and concerns, to adopt a flexible and effective measures, overcome difficulties, actively do a good job of college development / high staff to join the party work.

\section{Play ADVANTAGE ACCURATELY GRASP THE COLLEGE HIGH STAFF CHARACTERISTICS}

Outstanding contribution is the capability of independent innovation. Guangxi University, major person in charge of scientific research project leader, returned personnel are highly educated high titles of academic backbone or discipline construction core strength,

They are teaching, scientific research, management positions, in the implementation of the strategy of rejuvenating the construction of innovative country, advancing with the times, forge ahead, a strong capability of independent innovation and ability in organization and leadership, take the lead in implementing the party since reform and opening up the course policy, efforts to practice the important thought of Three Represents, follow the scientific outlook on development, especially on the development demand of advanced productivity with strong business sense, sufficient play as science and technology is the first productivity positive effect, with their outstanding contributions to promote the social and economic development. High status is with greater success and influence. Double high staff dedication, achievement is outstanding, get the school attaches great importance to, and rapid development momentum, the 211 Engineering construction especially in the scientific assessment, their personality charm and exemplary role, not only for staff and students have significant cohesion and influence, and their professional ability and level of knowledge in the community also has a great influence. Active opening, exploration sex is strong. Double high staff most have study abroad, study, visit experience, learn to accept new things, new ideas, know more advanced practice, to embody the characteristics of the times. From much angle, deep look, thought not to stick to one pattern, the courage to explore the forefront of science and technology new topic. Quick thinking independently is politically sensitive. Double high staff has a strong independent thinking ability, used to be my own observation and analysis to judge things, don't like being around, self-conscious; concerned about the political life of the country, concern of the party and state policies and the situation at home and abroad, and have their own unique insights. Teaching is imparting knowledge and educating people. The double 0 staff is teaching, scientific research, management of the backbone of the power, they both to teach and educate students, shouldering the imparting of knowledge, training builders and successors of the socialist cause of the heavy responsibility, in the teaching first line, knowledgeable, be of noble character and high prestige, with students in the communication process, influence and the infected students, deeply welcomed by the students. 
III. THOROUGH INVESTIGATION AND STUDY, PRACTICAL TO FIND OUT THE HIGH STAFF JOINING THE

\section{ATTITUDE}

Activists are less in number, of great significance. Dual number is little, its activist's number nature is little, but the development of double positive relations between the major molecular join or be admitted to the party. It is related to the socialist direction of running schools, related to building a socialist harmonious society talent training goal, the comprehensive construction well-off society's realization. Business development is light political progress. With the development of science and technology in the market competition advantage protruding shows, production personnel have significant business development, light political progress trend of thought. At the same time, as a result of colleges and universities in training academic leaders, study abroad for visit. Title assessment, not fully reflect the political conditions of the advantages, so that the high staff felt join the party for its own development was not affected by any. The business essence of life, deep knowledge, achievement as a major goal in life, devoted all his energy to the work; some think that did not join the party organization, also can be in the job for the school to contribute to social development. A few high staff to the party know, lack of confidence. Double high staff love Patriotic Party, is willing to contribute to the rich, strong and prosperous motherland, are looking forward to the party and the state power, the Chinese Communist Party led the Chinese people gained the success that attract worldwide attention, the comprehensive national power of our country increases apparently, but compared with the developed countries there is still a certain gap, with the deepening of reform and opening-up, mammon's, hedonism, bureaucratic erode the minority party members and cadres, there has been a small number of Party members and leading cadres power, corruption, bureaucratic corruption phenomenon, serious damage to the party the authority in people and figure, affects the high staff joining the enthusiasm; at the same time, as a result of world socialism, communism movement is in the low period, the disintegration of the Soviet Union, Eastern Europe, the production staff on the party's lack of confidence, socialist, communist ideal and belief are not firm enough. A few people utilitarianism thought is heavy, think Communist altruistic requirements

Office accommodation, will make oneself in the title evaluation, sent abroad to study and reduce the chance of joining the party, a few even worry to manacle, words and deeds not free, they consider is how to improve the operational level, in the work of talent showing itself as soon as possible, thus easing the political pursuit. There are a few double tall people tend to join a democratic party or independents. The Communist Party of China to strengthen the United Front work, pay attention to the talents recommend non-Party cadres in reserve, for the democratic parties and personages without party affiliation has more participation opportunities provided by a lot of ways and means, at the same time, some basic organization work due to lack of initiative, wait for the door, waiting for maturity, Party education, training of party a long time, material requirements Yan, link is much also, make double were demanding to join; in contrast, a high staff that other parties without investigation, low requirements, procedures simple, more social activities, promotion opportunities, famous degree tall, social influence. Thus tend to join a Democratic Party; others refused to join any party.

\section{RENEW IDEAS, INNOVATIVE HIGH STAFF WORK OF PARTY MEMBER DEVELOPMENT WAY}

Unified understanding, renew an idea, enhance the high staff positive guide. The school Party committee and organization of Party of each basic level in strategy to reinforce and improve the production staff members of working importance and pressing sex awareness, advancing with the times, blaze new trails, and further enhance the high staff of work of Party member development initiative, targeted and creative. Constantly strengthening the party construction of Party organization, and strive to improve the creativity, cohesion and fighting force based on the double, to increase staff $s$ ideal and belief and the party's basic knowledge education, deepen pair of people understanding to the party, enhance the high staff to Party confidence, help them establish correct world outlook, outlook on life and values, for the communist ideal practice and achieve personal ideals and aspirations. The ideas on the reform and innovation, change idea, give full consideration to university high staff characteristics, concrete analysis of specific situations, to positive education, eliminating the idea of demand perfection. Fully affirmed the achievements and mainstream universities high staff, on the double activists shortcomings, not demanding, mainly to see the actual performance, see mainstream, help them to develop the advantage, overcome the disadvantages, encouraging them to perform in business, political progress. Through the theory and practice, lead them to set up a lofty ideal of communism, and firmly take the road of the socialist road with Chinese characteristics the belief. In education, pay attention to the contents of the system and knowledge, connection is actual, not evade contradictions, high staff help correct view of the achievements and failures, objective understanding of the party a few corrupt behavior, dialectical thinking to reforming and opening and socialist market economy appears some problems, the correct analysis in transition of new old system I in our country a variety of difficulty and contradiction, implementing the spirit, implement the scientific outlook on development, organization of personnel involved in the service of science and technology such as high science and technology to the countryside of science and technology, caravans, congress battle and the activities of social practice and research, including the social problem, in the transition period of employment, education, migrant workers, medical insurance and other issues. Enhance the sense of responsibility and mission; hearten spirit, sturdy 
belief, for the training of qualified socialist builders and successors of the cause of contribution. In the development of high staff party work, my school lessons in high level talents academic culture business mentorship practices, party leaders personally responsible, political advisor and party organization to do double work personnel to join the party development. In my school, under the unified leadership of the Party committee, choose a batch of high political quality, strong sense of party spirit, can play a vanguard and exemplary role, masses foundation is good, in a subject field, outstanding academic prestige high leaders of science or business backbone members of experts and professors and college levels of the main leading cadres of the party as a political adviser. Political tutor actively cooperate with all two layers of mechanism Party branch do double activists work of education and training. Political instructors are generally responsible for one or a few with their professional disciplines similar or identical excellent teachers, in the service to the student to help guide, in the care of their living at the same time, also by irregularly and cultivation object of conversation, in politics in their biography, help, take, timely help, guide and a good grasp of their ideological and political state, improve their ideological and political consciousness, they induce in the continued political maturity. The initiative door-to-door service actively does a good job in university high staff job of development Party member. My school of cogent change job of development Party member, general wait for someone to make an application to join the party, and not to ignore, not pays regardless of the approach, truly: active, honest, patient and meticulous. Actively come to understand high personnel's thought tendency, with double high staff talk friend, help double high staff to set up the correct world outlook, outlook on life, values, and guide them to move closer to the party, the conditions are ripe, interested in joining the Party comrades, especially the social impact of large, professional personage, advance column key object,

Assignment of political instructor, Party branch responsible person, Party member responsible for whole process of culture education, the care on the life, work pressure burden, in business, in accordance with the principle of have both ability and political integrity, the good political quality, high level of knowledge, business skills of excellent talents and assigned to teaching, research and management and other important positions the importance of teaching, scientific research work to double take, so that they receive training and test. A bold attempt is flexible and effective inspection training methods, training a good pair of Party activists. According to emancipate the mind, seek truth from facts principle. To do: in principle are flexible, flexibility in adherence to the principles of. Proper consideration is given to the high staff teaching and research tasks, teaching and scientific research management carries on both shoulders and other characteristics, taking both with the requirements of the party constitution, but with double high personnel actual inspection training mode. School for double high staff characteristics and the actual situation, through holding dual personnel party knowledge training class, conversations, establish high staff online party knowledge learning, self-study and write position experience or thesis, spare time reading notes, oral report form, the double high personnel system of the party basic knowledge of Marxism-Leninism, Mao Zedong thought, Deng Xiaoping theory, the important thought of Three Represents, and the scientific outlook on development education and party spirit education, make them deepen their understanding of Marxism basic theory, basic line of the party and the party's basic knowledge, further strengthen the communist ideal and belief in socialism, and firmly take the road of socialism with Chinese characteristics confidence and determination, and strive to cultivate the party ideology; at the same time and teaching assessment, scientific research problem, end of year assessment, debriefing report way of combining inspection double staff political performance, take the teacher Party member contact admissions activist, leader cadre of College Party branch members affiliated branch association measures such as cultivating high party activists. Simplified admission procedures and formalities, in accordance with the / adhere to standards, quality assurance, improving the structure, discreet development principles, adhere to the development of a mature one principle, provide excellent high personnel absorbed into the party in years. Our school actively develops activity of advanced sex education, to strengthen the basic level organization of the party's construction. The party's ideological construction, style construction, organization construction and the system construction is put in outstanding and significant position, give full play to the party's leadership core, the political core, the battle fort effect, in the order of 211 works as a leader, to the key discipline construction as the core, taking the undergraduate teaching level evaluation as the focus of the reform and development of the school, and give full play to reflect the advanced nature of the party and the party organization actively, improve teaching quality and school running level, enhance scientific research strength, effort in subjects construction efforts, improve our overall strength. Strengthening the education on Party members' advancement, and effectively improve the quality of Party member teachers, give full play to the exemplary vanguard role of Party members, Party committee and administrative work, and the construction of Party branch and Department of discipline construction, organization of life and teaching combination to maintain and reflects the advanced sex of the Communist, constantly enhance the combat effectiveness of the party, cohesive affinity to high officers in the party organization to attract. The political culture and business improve organically. Strengthen the political quality is good in both personnel training business backbone, in high quality business / double 0 personnel training core political work, the ideological and political construction of double tall personnel and business quality culture organically together. School of government and various departments 
cooperate closely, in party card cadre selection, the selection of professional academic leaders, the backbone teachers training and team construction of teachers in the new century, in the double high staff to go abroad for further study, titles, actor awards and other work, adhere to the score as a main reference, take to adhere to the correct policy guidance, put forward and carry out the ideological and political quality and professional ability to work two requirements. Commend advanced publicity, play the typical demonstration effect. In order to strengthen the party in the high officers in the force and centripetal force, prominent characteristics of the times, progressive, pioneering, actively carry out the characteristics of Guangxi University Party Committee Party Day activities, first to excellence, every 6- July organization of Party of each basic level to carry out the corresponding to remember the birthday party, party, Party oath in my heart and my contribution to add for Party glory and other special activities, each judge 2 years

Choose an organization of Party of advanced basic level, outstanding Party member and worker of outstanding party work, through the website, newspaper column, extensive conduct propaganda is advanced and typical achievement especially Key Laboratory of Party branch, Chang jiang Scholars Program, distinguished professor of CPC Representing the national outstanding communist party member Chen Bao shan advanced achievement, digging the fine double 0 members of flash point, with real, fresh example inspire staff enthusiasm and high political enthusiasm. At the same time, through the cultivation of double excellent Party member, make excellent high Party comrades assume some posts within the party, positive for double excellent Party member holds the position of Party organizations to create the conditions.

\section{ACKNOWLEDGEMENTS}

The paper is supported by 2012 Jiangxi Province College Party Construction Project (No. JXGXDJ201211)

\section{REFERENCES}

[1] Wei, L. \& Hindman, D. (In press). Does the digital divide matter more? Comparing the effects of new media and old media use on the education-based knowledge gap. Mass Communication and Society.

[2] National Telecommunications and Information Administration. (1998). Falling through the net II: New data on the digital divide. Retrieved May 15, 2009, from http://www.ntia.doc.gov/ntiahome/net2/falling.html; Selwyn, N. (2004). Reconsidering political and popular understandings of the digital divide. New Media \& Society, 6, 341-362.

[3] Yu, L. (2006). Understanding information inequality: Making sense of the literature of the information and digital divides. Journal of Librarianship and Information Science, 38(4), 229-252.

[4] Attewell, P. (2001). The first and second digital divides. Sociology of Education, 74, 252-259.

[5] Hargittai, E. (2002). Second-Level digital divide: Differences in people's online skill. First Monday, 7(4). Retrieved January 15, 2005, from http://firstmonday.org/issues/issue7_4/hargittai/\#author

[6] Hargittai, E., \& Hinnant, A. (2008). Digital inequality: Differences in young adults' use of the Internet. Communication Research, 35, 602-621.

[7] Jung, J.-Y., Qiu, J. L., \& Kim, Y.-C. (2001). Internet connectedness and inequality: Beyond the "divide". Communication Research, 28, 507-535.

[8] Bonfadelli, H. (2002). The Internet and knowledge gaps: A theoretical and empirical investigation. European Journal of Communication, 17, 65-84; Van Dijk, J. (2002). A framework for digital divide research. Electronic Journal of Communication, 12. $\begin{array}{llll}\text { Retrieved January 15, 2004, from } & \text {, }\end{array}$ http://shadow.cios.org:7979/journals/EJC/012/1/01211.html 